\title{
The Profile of Critical Incidents During Online PBL Tutorial Based on Students' Perception
}

\author{
Catharina Widiartini $^{*}$, Joviando ${ }^{1}$, Fajar Wahyu Pribadi ${ }^{1}$ \\ ${ }^{1}$ Study in Faculty of Medicine, Jenderal Soedirman University \\ *Corresponding author. Email: catharina.widiartini@unsoed.ac.id
}

\begin{abstract}
Background. Online PBL tutorials were conducted to comply with social distance requirements during the Covid19 pandemic. Critical incidents (CIs) due to the new learning environment may cause group dysfunctionality. Data of CIs based on student's perception was necessary for evaluation purposes, especially due to the unknown ending of the pandemic.

Method. The questionnaire in google-form format was self-assigned by 249 students of The Faculty of Medicine, Jenderal Soedirman University, Batch 2017-2019. The first part of the questionnaire consisted of 44 examples of $6 \mathrm{CI}$ factors adopted from previous studies that used offline tutorial context. Respondents were asked to identify the frequency of occurrence of each CI. They may report other CIs, especially those related to the online nature of the tutorial. The second part of the questionnaire asked the respondents to identify the CI factor that was the most frequently happened, the most disturbing to the task and group functioning, and the most needed tutor intervention.

Result. Most students reported that 34 out of 44 critical incidents never happened. "Challenged by the tutorialtrying hardly to search for and answer all of the learning issues" was always, almost always, and not always happened. Most students perceived that: the participation imbalance was the most frequently happened; lack of interaction was the most disturbing to the task functioning as well as to the group functioning and the lack of motivation was the most needed tutor intervention. Issues related to the online nature of the tutorial were mostly related to the unstable internet connection and the disadvantages of using different discussion platforms.

Conclusion and recommendation. The CIs reported are quite similar to the offline context. PBL tutorial development programs may be prioritized on the CI factors that need attention. A similar study based on the tutor's perception is needed to complement the analysis.
\end{abstract}

Keywords: critical incident, online, PBL, tutorial.

\section{INTRODUCTION}

The COVID-19 pandemic in early 2020 has caused sudden changes from offline toward online learning methods delivery in The Faculty of Medicine, Jenderal Soedirman University (FK Unsoed). Unpreparedness in many areas and the requirement for quick adaptation might be stressful for the students as well as the faculties. The situation might cause some critical incidents (CIs) in learning activities, including Problem-Based Learning (PBL) group discussions (tutorials) [1][2]. CIs are all forms of events, experiences, episodes, etc. that occur during group discussions, which can affect the group dynamics in fulfilling their task as well as group functions [3]. Data of CIs based on student's perception was necessary for evaluation purposes, especially due to the unknown ending of the pandemic.

\section{METHOD}

This was a cross-sectional, survey-based quantitative study. The $1^{\text {st }}$ Author prepared a selfassigned questionnaire in a google form format and received ethical clearance from the Ethical Committee of FK Unsoed. The questionnaire was distributed to students of Batch 2017, 2018, and 2019 at the scheduled time determined by the Quality Assurance Unit of FK Unsoed to ensure that students did not oblige to fill out too many different kinds of questionnaires with different purposes in a short time. The questionnaire was distributed after the students have conducted the last meeting of the fully online PBL tutorial of the fourth Block of the semester. This was around May 2020, 2 months after the onset of online learning conducted at FK Unsoed. The students were given 24 hours to fill out and submit the questionnaire. Of the 343 total 
students, only 249 data met the inclusion criteria, namely full attendance in all of the online PBL tutorials conducted as confirmed by the $\log$ of attendance.

The questionnaire consisted of 2 parts. Part I aimed at obtaining the frequency of occurrence data from each critical incident example stated. Part II aimed at obtaining the general perception regarding CI factor from 4 parameters, namely: 1) the most frequently occurred; 2) the most disturbing to the task functioning; 3 ) the most disturbing to the group functioning; 4) the most needed tutor intervention.

Part I of the questionnaire consisted of 44 sample statements of CIs modified from the previous studies by Dolmans et al. [4], De Grave et al. [5], and Fitri et al.[6]. The examples of CIs were representations of the cognitive and motivational dimensions of critical incidents. The cognitive dimension consists of 2 factors, namely lack of elaboration and lack of interaction. The motivation dimension consists of 4 factors, namely lack of participation, difficult personalities, lack of cohesion, and lack of motivation.

For each CI, the respondent was asked to determine whether it was always, almost always, not always (but quite often), sometimes/rarely, or never happened. "Always" means that the CI was always found each time of the PBL tutorial meeting. "Almost always" means that the CI was found at least in 1 of 2 meetings of each PBL case series (One PBL case series consisted of 2 tutorial meetings). "Not always (but quite often)" means that the CI was not always found in each PBL case series, however it was not uncommon. "Sometimes/rarely" means that the CI was uncommon or at least had happened once. "Never happened" means that the CI was never found, even at once. The frequency of occurrence chosen was based on the two months of experience attended fully online PBL tutorials. At the time of data collection, students have concluded 7 PBL case series or 14 PBL tutorial meetings.

At the last of the questionnaire part I, there was 1 open-ended question that asked respondents to mention any other CI they have encountered that was not already mentioned in the questionnaire, including the type of the frequency of occurrence. This was especially related to the online nature of the group discussion.

\section{RESULTS}

In each batch, female students outnumbered males and altogether made a proportion of 179: 70 .

\subsection{Result of Questionnaire part 1:}

For each of the 44 CI statements, we counted the number of the response to each of the 5 types of the frequency of occurrence [always, almost always, not always (but quite often), sometimes/rarely, never happened], then converted it into a percentage of the total response. Here in Table 1 we only show the 3 CIs with the highest percentage in each CI factor.

We then classify the data based on the type of the frequency of occurrence [always, almost always, not always (but quite often), sometimes/rarely, never happened]. Table 2 shows 3 CIs with the highest percentage of response in each of 5 types of the frequency of occurrence.

\subsection{Result of an open-ended question}

Some CIs not mentioned in the questionnaire reported by the students as follow:

"There was some degree of flexibility allowed in conducting a discussion. It was not uncommon that the tutor's availability was outside working hours or in variable time across several discussions."

"The tutor kindly gave us learning resources abundantly, but unfortunately, I felt overwhelmed".

Issues related to the online nature of the tutorial were mostly related to the unstable internet connection and some disadvantages of using certain kinds of discussion platforms (videoconferencing, such as Zoom or Google Meet, or text messager, such as Whatsapp).

Regardless of the discussion platform, an unstable internet connection might cause the slowing down of the discussion due to lagging while speaking, sharing screen/voice note/picture/text. The slowing down was also caused by students or tutors who were not familiar with the platform used. Those CIs may irritate other group members and decreased their motivation. On the other hand, the slow student himself might feel left behind.

Issues related to the disadvantages of using video-conference discussion platform were as follow.

"The unstable internet connection could hinder someone from seeing another's camera display".

"Without seeing student's body language and activities, tutors could not fully observe, supervise, assess and give feedback to the group. This caused the use of a videoconference could not be maximized. Despite the increased expense, nothing is superior to the messenger platform". 
"The invisible camera displays also made some students were tempted to do other activities not related to discussion (e.g. sleeping, playing games, chatting)".

However, being seen through camera display, a student reported that it made him feel less relaxed, always have to be in a neatly seated position. Another student reported that silent moments during discussion have become uncomfortable and he/she was burdened with having to say anything immediately to fill in the quietness. Finally, to minimize those distractions during video conferencing, students must provide more budget for a stable internet connection.

Some disadvantages of using a text messenger platform were mostly the opposite of the advantages of using a videoconference platform. One example as follow:
"Silent moments could be very long, thus tutors who did not know what the discussion participants were doing would have become increasingly impatient. The moderator was forced to push his group up. If group members still did not respond, there will be some tension felt among members and/or with the tutor"

In using the messenger platform, students who preferred to speak immediately felt some obstacles in expressing their opinions in writing. Even though they could use the voice note tool, it still took time to record and then listened to by other members. On the contrary, students who love to write felt some advantages of not speaking directly. Some students reported that they felt impatient with those who were slow in typing. Meanwhile, those who were slow typing felt inconvenience and not uncommonly, felt left behind.

Table 1. The 3 CIs with the highest percentage of response in each CI factor

\begin{tabular}{|c|c|c|c|c|}
\hline \multirow[b]{2}{*}{ Cl factor } & \multirow[b]{2}{*}{ Item } & \multicolumn{3}{|c|}{ The highest percentage of response } \\
\hline & & Cl: "There was someone who..." & $\begin{array}{l}\text { Frequency of } \\
\text { occurrence }\end{array}$ & $\%$ \\
\hline \multirow{3}{*}{$\begin{array}{l}\text { lack of } \\
\text { elaboration }\end{array}$} & 8 & provided substantially wrong information. & never & 83.94 \\
\hline & 7 & deliberately skipped a discussion of a learning goal. & never & 74.70 \\
\hline & $9 \& 10$ & conveyed opinions or assumptions as facts. & never & 67.07 \\
\hline \multirow{3}{*}{$\begin{array}{l}\text { lack of } \\
\text { interaction }\end{array}$} & 2 & $\begin{array}{c}\text { shared figures /text excerpts without any attempt to } \\
\text { paraphrase/to explain. }\end{array}$ & sometimes/rarely & 39.76 \\
\hline & 3 & $\begin{array}{c}\text { did not provide comments or appreciation for the } \\
\text { other's contributions. }\end{array}$ & $\begin{array}{c}\text { sometimes/rarely }= \\
\text { never }\end{array}$ & 37.75 \\
\hline & 1 & $\begin{array}{l}\text { shared opinions or information at length, without } \\
\text { confirming other's understanding. }\end{array}$ & sometimes/rarely & 36.55 \\
\hline \multirow{3}{*}{$\begin{array}{c}\text { lack } \\
\text { (imbalance) } \\
\text { of } \\
\text { participation }\end{array}$} & 15 & $\begin{array}{l}\text { contributed minimally or never contribute because of } \\
\text { the confidence barrier. }\end{array}$ & never & 83.94 \\
\hline & 14 & $\begin{array}{l}\text { contributed minimally or never contribute because of } \\
\text { technical problem related to the discussion platform } \\
\text { (e.g. slow typer, not familiar with the platform) }\end{array}$ & never & 74.70 \\
\hline & 16 & $\begin{array}{l}\text { contributed minimally or never contribute because of } \\
\text { not having the information. }\end{array}$ & never & 67.07 \\
\hline \multirow{3}{*}{$\begin{array}{l}\text { difficult } \\
\text { personalities }\end{array}$} & 39 & could not accept criticism/suggestions. & never & 83.13 \\
\hline & 44 & $\begin{array}{l}\text { contributed minimally or never contribute because } \\
\text { want to try, even though they have been admonished. }\end{array}$ & never & 81.53 \\
\hline & 40 & $\begin{array}{l}\text { wanted to be stand out / attracted the tutor's } \\
\text { attention. }\end{array}$ & never & 80.32 \\
\hline \multirow{3}{*}{$\begin{array}{l}\text { lack of } \\
\text { cohesion }\end{array}$} & 32 & $\begin{array}{l}\text { impressed to have interpersonal conflicts/tensions } \\
\text { with the tutor. }\end{array}$ & never & 93.17 \\
\hline & 21 & $\begin{array}{l}\text { more often jokes or anecdotes than information } \\
\text { relevant to the tutorial. }\end{array}$ & never & 91.57 \\
\hline & 31 & $\begin{array}{l}\text { was impressed to have interpersonal } \\
\text { conflicts/tensions with other students. }\end{array}$ & never & 88.76 \\
\hline \multirow{3}{*}{$\begin{array}{l}\text { lack of } \\
\text { motivation }\end{array}$} & 33 & $\begin{array}{c}\text { was being late in attending discussions due to } \\
\text { seemingly artificial reasons/problems that should } \\
\text { have been anticipated. }\end{array}$ & never & 80.32 \\
\hline & 34 & $\begin{array}{c}\text { was impressed to have not been well prepared due to } \\
\text { seemingly artificial reasons/problems that should } \\
\text { have been anticipated. }\end{array}$ & never & 77.51 \\
\hline & 38 & $\begin{array}{l}\text { contributed minimally or never contribute because } \\
\text { he/she did not like group discussion as a learning } \\
\text { method. }\end{array}$ & never & 59.04 \\
\hline
\end{tabular}


Table 2. The 3 CIs with the highest percentage of response in each type of the frequency of occurrence

\begin{tabular}{|c|c|c|c|c|}
\hline \multirow{2}{*}{$\begin{array}{l}\text { Frequency of } \\
\text { occurrence }\end{array}$} & \multirow{2}{*}{ Item } & \multicolumn{3}{|c|}{ The highest percentage of response } \\
\hline & & Cl: "There was someone who..." & Cl factor & $\%$ \\
\hline \multirow{3}{*}{ always } & 17 & $\begin{array}{l}\text { Was challenged by group discussions (was trying } \\
\text { very hard to find and master all learning objectives) }\end{array}$ & $\begin{array}{l}\text { lack (imbalance) } \\
\text { of participation }\end{array}$ & 10.44 \\
\hline & 1 & $\begin{array}{c}\text { shared opinions or information at length, without } \\
\text { confirming other's understanding. }\end{array}$ & $\begin{array}{c}\text { lack of } \\
\text { interaction }\end{array}$ & 7.63 \\
\hline & 6 & $\begin{array}{c}\text { did not try to understand/criticize/provide } \\
\text { comments/ask question regarding information } \\
\text { submitted by friends }\end{array}$ & $\begin{array}{l}\text { lack of } \\
\text { elaboration }\end{array}$ & 3.21 \\
\hline \multirow{3}{*}{ Almost always } & 17 & $\begin{array}{l}\text { Was challenged by group discussions (was trying } \\
\text { very hard to find and master all learning objectives) }\end{array}$ & $\begin{array}{l}\text { lack (imbalance) } \\
\text { of participation }\end{array}$ & 22.49 \\
\hline & 1 & $\begin{array}{l}\text { shared opinions or information at length, without } \\
\text { confirming other's understanding. }\end{array}$ & $\begin{array}{c}\text { lack of } \\
\text { interaction }\end{array}$ & 13.25 \\
\hline & 2 & $\begin{array}{c}\text { shared figures /text excerpts without any attempt to } \\
\text { paraphrase/to explain. }\end{array}$ & $\begin{array}{c}\text { lack of } \\
\text { interaction }\end{array}$ & 10.84 \\
\hline \multirow{3}{*}{$\begin{array}{l}\text { not always (but } \\
\text { quite often) }\end{array}$} & 17 & $\begin{array}{l}\text { Was challenged by group discussions (was trying } \\
\text { very hard to find and master all learning objectives) }\end{array}$ & $\begin{array}{l}\text { lack (imbalance) } \\
\text { of participation }\end{array}$ & 32.13 \\
\hline & 1 & $\begin{array}{c}\text { shared opinions or information at length, without } \\
\text { confirming other's understanding. }\end{array}$ & $\begin{array}{c}\text { lack of } \\
\text { interaction }\end{array}$ & 23.69 \\
\hline & 6 & $\begin{array}{c}\text { did not try to understand/criticize/provide } \\
\text { comments/ask question regarding information } \\
\text { submitted by friends }\end{array}$ & $\begin{array}{l}\text { lack of } \\
\text { elaboration }\end{array}$ & 22.89 \\
\hline \multirow{3}{*}{ sometimes/rarely } & 39 & $\begin{array}{c}\text { contributed minimally or never contribute because of } \\
\text { not having the information. }\end{array}$ & $\begin{array}{l}\text { lack (imbalance) } \\
\text { of participation }\end{array}$ & 59.44 \\
\hline & 5 & $\begin{array}{c}\text { was providing opinions / information in a very shallow } \\
\text { / concise / general manner, without the necessary } \\
\text { elaboration / details }\end{array}$ & $\begin{array}{l}\text { lack of } \\
\text { elaboration }\end{array}$ & 51.00 \\
\hline & 15 & $\begin{array}{l}\text { contributed minimally or never contribute because of } \\
\text { the confidence barrier. }\end{array}$ & $\begin{array}{c}\text { lack of } \\
\text { participation }\end{array}$ & 45.38 \\
\hline \multirow{3}{*}{ never happened } & 32 & $\begin{array}{l}\text { impressed to have interpersonal conflicts/tensions } \\
\text { with the tutor. }\end{array}$ & lack of cohesion & 93.17 \\
\hline & 21 & $\begin{array}{l}\text { conveyed jokes or anecdotes more often than } \\
\text { information relevant to the tutorial. }\end{array}$ & lack of cohesion & 91.57 \\
\hline & 29 & $\begin{array}{l}\text { was seen to be uncomfortable because he/she is a } \\
\text { retaker student. }\end{array}$ & lack of cohesion & 89.16 \\
\hline
\end{tabular}

\subsection{The results of Questionnaire part 2:}

The general perception of the CI factor regarding the 4 parameters is as shown in Table 3 . In 3 parameters, namely 1) the most frequently occurred; 2) the most disturbing to the task functioning; 3) the most disturbing to the group functioning, the results were similar in total response as well as in each of the 3 batches. Students of Batch 2017 and 2018 responded differently to students of Batch 2019 regarding the $\mathrm{CI}$ factor that was the most needed tutor intervention.

Table 3. The general perception of CI factor regarding 4 parameters

\begin{tabular}{|c|c|c|c|c|}
\hline \multirow{2}{*}{ Cl factor perceived as: } & \multicolumn{4}{|c|}{$\mathrm{Cl}$ factor (\% of response) } \\
\hline & Batch 2017 & Batch 2018 & Batch 2019 & altogether \\
\hline the most frequently occurred & $\mathrm{A}(41,90 \%)$ & $A(54,29 \%)$ & $\mathrm{A}(31,08 \%)$ & $A(42,17 \%)$ \\
\hline the most disturbing to the task functioning & $\mathrm{B}(26,67 \%)$ & $\mathrm{B}(22,86 \%)$ & $\mathrm{B}(33,78 \%)$ & B $(27,71 \%)$ \\
\hline the most disturbing to the group functioning & $\mathrm{B}(31,43 \%)$ & $\mathrm{B}(25,71 \%)$ & $\mathrm{B}(30,14 \%)$ & B $(29,32 \%)$ \\
\hline the most needed tutor intervention & A $(28,57 \%)$ & $\mathrm{A}(27,63 \%)$ & C $(29,73 \%)$ & $C(26,10 \%)$ \\
\hline
\end{tabular}

$\mathrm{A}=$ lack (imbalance) of participation; $\mathrm{B}=$ lack of elaboration; $\mathrm{C}=$ lack of motivation

\section{DISCUSSION}

Based on the largest proportion of students answer regarding the frequency of the occurrence of each CI, we found that 34 out of the total 44 stated 
CIs were perceived by most students as never happened'; 8 CIs as sometimes/rarely happened; 1 CI, namely "did not provide comments or appreciation for the other's contributions" as never happened as much as sometimes/rarely happens; 1 CI namely "challenged by group discussions (was trying very hard to find and master all learning objectives)" as not always (but quite often); no CI had the largest proportion of students answer as always happened. This result was as expected, since the more CIs found during group discussions, the bigger the potential for a group to be dysfunctional [6]. However, albeit found in a small percentage, there were still found various CIs with the highest proportion of students answer as always, almost always, and not always (but quite often). The CIs found in these 3 types of occurrence frequency should be our priority of attention.

From Table 2, 2 CIs, namely "was challenged by group discussions (was trying very hard to find and master all learning objectives)" and "shared opinions or information at length, without confirming other's understanding" were the top 2 in the 3 types of occurrence frequency which need our priority of attention. Likewise, the 3 factors that cause CIs, namely: lack (imbalance) of participation, lack of interaction, and lack of elaboration.

Meanwhile, the top $3 \mathrm{CIs}$ that perceived as never happened were under the factor of lack of cohesion factor. The latter means that students probably did not have any cohesion problem. Cohesion which is under the motivation factor of group functionality is related positively to task function because everyone is willing to collaborate for the group's success [4]. It relates to the finding that the CI factor that was perceived as the most disturbing to task functioning was not cohesion problem but lack of interaction.

\subsection{The most frequently occurred CI factor}

The results showed that the most common factor was lack or imbalance of group member participation. This supports the findings reported in De Grave et al. [5] and Fitri et al. [6]. The presence of students who seem challenged by group discussions (trying very hard to find and master all existing learning objectives) was the most common $\mathrm{CI}$ in this factor. Students' efforts to achieve all of the learning outcomes should be appreciated as a good thing in terms of responsibility for learning assignments. However, it can cause a problem or become a CI if he/she turns to be dominating the discussion. The dominant student tries to present his/her work without considering the learning context which is a group discussion. Domination can also encourage other members to be passive since they no longer have anything to say about or were simply amazed by the thoroughness, regardless of the correctness. Although this does not cause tension or affect group cohesion, this may affect the effectiveness of PBL group discussions. PBL group discussions encourage students to interact with each other equally. Interaction with fellow group members can help students to form new understandings about a problem [4].

The tutor's lack of understanding of his role can contribute to this problem. Tutors must be able to function as facilitators, activators, and stimulators. Tutors must be able to encourage all members of the group to actively participate in discussions to achieve learning goals [5]. The importance of the collaboration aspect is also emphasized by Broadbent \& Poon [7] in a systematic review of selfregulated learning strategies in the context of online learning. It was stated that the peer learning strategy is closely related to academic achievement. Thus, the tutor may encourage students to develop peer learning strategies through group discussion as well as other online learning methods.

In online PBL group discussions, problems of internet connection stability, typing speed, searching, or browsing speed can hinder students to participate and increasing their feeling of isolation. As mention by Baden [8], any missed part of the discussion may add to some difficulty in following the progress and the overall understanding of the topic discussed. Moreover, as mentioned by Cheaney \& Ingebritsen [9], the absence of timely feedback and visual clues (pictures/videos) as well as a lack of non-verbal contact, leading to misinterpretation. Problems like this were also reported in this study. Several students reported that they felt left behind, irritated, and demotivated due to those CIs.

Nevertheless, the CIs related to the online nature of the discussion seemed to be not significant. Only several students reported the abovementioned CIs in the open-ended questioned. Moreover, CIs in the first 44 examples CIs in questionnaire part 1, namely "being late to join/attend the discussion because of internet connection problem"; "failed to join/attend the discussion due to internet connection constraints"; "never or little to contribute in the discussion due to internet connection problems (even though they have the information)" get the most answers for the type of frequency "never happened".

\subsection{CI factor that was the most disturbing to task functioning}

Task functioning is the ability of a group to carry out its academic tasks [3]. This study found that what most disturbed the task functioning was the 
lack of interaction between group members $(27.71 \%)$. This finding was also found to be the same in each batch. The top 3 CIs in this factor implied that they who did the CsI did not synthesize knowledge and did not apply it to the problem at hand [10]. This was exacerbated by presenters who did not try to seek feedback from their peers, whether they understand, and vice versa, meanwhile other students did not respond to the presentation critically and tend to accept it. Situations like this hinder the quality of group interactions and the achievement of some group discussion objectives. Group interaction should lead to the development of critical thinking through cognitive processes such as elaborating opinions, summarizing information gathered, monitoring learning, and applying knowledge and professional skills in teams [5][11].

\subsection{CI factor that was the most disturbing to the group functioning}

Group functioning is the functioning of a group related to the dynamics, or interactions between group members [3]. The success of group functioning can be assessed from group interactions. The group interaction is influenced by the perceptions of students and tutors, the skills of tutors and students in managing group dynamics, and the suitability of the tutor's expertise with the topic of discussion [12].

In offline or face-to-face PBL group discussions, becoming familiar with other group members is more effective than in online discussions. Building good relationships between group members will make work more effective and can also reduce the potential for misunderstandings. For many students, factors that contribute to building this good relationship include an atmosphere of trust, respect, common goals, and a supportive presence for other group members [13][14]. In this study, the CI factor perceived as the most disturbing to the group functioning was the imbalance of interactions between group members. This factor was chosen by $29.31 \%$ of the total respondents. This finding was also found to be the same in each batch.

"There was someone who shared opinions or information at length, without confirming other's understanding." was the second top CIs that were always, almost always, and not always (but quite often). This relates to what Azer \& Azer [12] have said that group interactions in PBL tutorials can be hindered by competition between students in groups. Such a competitive attitude can be fostered by a campus assessment policy in which the performance of one student is often compared to other students without considering collaborative learning, teamwork, and co-learning aspects. Such competition can weaken relationships between students, hinder collaborative learning and encourage deep learning

\subsection{CI factor that was most needed tutor intervention.}

There were differences among the batch regarding the factor that most needed tutor intervention. Classes of 2017 and 2018 perceived that imbalance of participation was the most needed tutor intervention. The second was the lack of motivation factor. The 2019 class perceived that lack of motivation was the most needed tutor intervention. The same result when the total respondents' answers were calculated (26.10\%). These results were in line with a study by Fitri et al. [6].

An interesting result in this study was that although the lack of motivation was not the most common factor, it was considered as the most needed tutor intervention. This means that a tutor is expected not only to stimulate the learning process but also to have a motivational strategy to stimulate the group. According to Fitri et al. (2013), lack of motivation is the factor that most requires tutor intervention. Lack of motivation can create a "parasitic" situation. In this situation, lazy students would prefer to ask other students about various things and the resources used. Tutors may intervene by acting as an activator to increase their internal motivation. Tutors should have skills in asking prompting questions to help them to be aware of their previous knowledge then relate it to the present issue, being aware of their weaknesses and lack of knowledge to be addressed. Tutors must stimulate students to study independently, finding out about the topic being discussed comprehensively [5]. By motivating students' desire to study independently, optimizing their self-control, and minimizing or anticipated their anxiety may affect students' desire to study independently [15].

As already mentioned before, some problems related to the unstable internet connection, both related to and not related to certain discussion platforms used could cause demotivation. This emphasized the influence of external factors on students' (as well as tutor's) motivation. Some efforts to maintain and increase students' motivation during online learning discussion can be in the forms of the availability of facilities, especially stable internet connection, good quality scenario, skillful and dedicated tutor (including dedicated time for fixed/regular/schedule tutorials) [9][16].

\subsection{Research Limitations}


The data used in this study was the student's perception only. There is a need for further research on tutors' perspectives regarding critical incidents in group discussions. The concordance of perceptions between tutors and students regarding CIs may help the institution to focus on the tutor training needs.

Although CIs related to the online nature of the discussion were reported by only several students, it could be caused by a limited number of specific CIs examples given in the questionnaire. They might simply do not think about them. The questionnaire used in this study was based on previous similar studies that used offline context. Therefore, it is necessary to devise a more appropriate questionnaire with examples of CIs related to the continually developing online PBL tutorial learning experiences.

\section{CONCLUSION}

The CIs reported in online PBL tutorials in FK Unsoed were quite similar to the findings of previous studies in offline PBL tutorials. Most CIs were perceived as never happened. However, the curriculum developers may use the results in this study for constructing a PBL tutorial development program for the tutors as well as the students. Such a program to make improvements in conducting online PBL group discussions may be focused or prioritized on the 3 CIs factors that need attention, namely: lack (imbalance) of participation, lack of interaction, and lack of elaboration A similar study based on the tutor's perception is needed to complement the analysis.

\section{AUTHORS' CONTRIBUTIONS}

All of the three authors are affiliated at The Faculty of Medicine, Jenderal Soedirman University (FK Unsoed), Central Java, Indonesia. Catharina Widiartini and Fajar Wahyu Pribadi are lecturers and Jofiando is a medical student. The first author contributed to the questionnaire development, final report writing, and authoring this article. The other authors contributed to the data analysis and final report writing.

\section{ACKNOWLEDGMENT}

The authors appreciate the help of Gugus Pengendali Mutu (Quality Assurance Unit) of FK Unsoed in the dissemination of the questionnaire.

\section{REFERENCES}

[1] S. Rose, Medical student education in the time of COVID-19, JAMA (2020). DOI: https://jamanetwork.com/journals/jama/fullart icle/2764138

[2] S. Weiner, No classroom, no clinics: Medical education during a pandemic, AAMC (2020). DOI: https://www.aamc.org/news-insights/noclassrooms-no-clinics-medical-educationduring-pandemic

[3] R.F. Bales, Takes role and social role in problem-solving groups, New York: Knopf, 1958.

[4] D.H. Dolmans, I.H. Wolfhagen, C.P. Van Der Vleuten, Thinking about student thinking: motivational and cognitive processes influencing tutorial groups, Academic Medicine, 73(10) (1998) 22-24.

[5] W.S. De Grave, D.H. Dolmans, C.P. Van Der Vleuten, Student perspectives on critical incidents in the tutorial group, Advances in Health Sciences Education. 7(3) (2002) 201206.

[6] A.D. Fitri, H. Mardiwiyoto, E. Suryadi, Persepsi mahasiswa dan tutor tentang kejadian kritis selama diskusi tutorial dan jenis-jenis interview terhadap kejadian tersebut. The Indonesian Journal of Medical Education, 2(3) (2013) 159-173.

[7] J. Broadbent, W.L. Poon, Self-regulated learning strategies and academic achievement in online higher education learning environments: A systematic review, The Internet and Higher Education, 27 (2015) 1-13.

[8] M.S. Baden, A practical guide to problembased learning online. New York: Routledge, 2007.

[9] J.D. Cheaney, T. Ingebritsen, Problem-based learning in an online course: A case study, The International Review of Research in Open and Distributed Learning, 6(3) (2005).

[10] M.M. Van den Hurk, D.H. Dolmans, I.H. Wolfhagen, A.M. Muijtjens, C.P. van der Vleuten, Impact of individual study on tutorial group discussion, Teaching and Learning in Medicine. 11(4) (1999) 196-201.

[11] P. Kindler, C. Grant, S. Kulla, G. Poole, W. Godolphin, Difficult incidents and tutor interventions in problem-based learning tutorials, Medical Education 43(9) (2009) 866873. 
[12] S.A. Azer, D. Azer, Group interaction in problem-based learning tutorials: A systematic review, European Journal of Dental Education,19(4) (2015) 194-208.

[13] D. McConnell, Implementing computersupported cooperative learning. London: Kogan Page 2000.

[14] R. Palloff, K. Pratt, Lessons from the cyberspace classroom, San Francisco: John
Wiley and Sons 2001.

[15] G.D. Hendry, M. Frommer, R.A. Walker, Constructivism and problem-based learning, Journal of Further and Higher Education, 23(3) (1999) 359- 70.

[16] M.S. Baden, C.H. Major, Foundations of Problem-based Learning, New York: Routledge 2004. 